\title{
Effects and correlation analysis of different host-plant components on physiological indexes in Spodoptera frugiperda
}

\author{
Min Fang ${ }^{1}$, Sihan $\mathrm{Lu}^{1}$, Ling Yao ${ }^{1}$, Renwen Zheng ${ }^{1}$, Jianhua Huang ${ }^{2}$, Guiting $\mathrm{Li}^{1}$, and \\ Qingfeng Tang ${ }^{1}$ \\ ${ }^{1}$ Anhui Agricultural University \\ ${ }^{2}$ Zhejiang University - Zijingang Campus
}

July 7, 2021

\begin{abstract}
Spodoptera frugiperda (Lepidoptera: Noctuidae) is an invasive pest that ravaging crops in many provinces of China. In order to specifically control this invasive pest, understanding of the relationship between the insect and the host is necessary. In this study, we have compared the biological and nutritional indexes of S. frugiperda by feeding it with five different host-plants (Zea mays, Triticum aestivum, Digitaria sanguinalis, Glycine max and Eleusine indica). The biological and nutritional indexes of Z. mays feeding S. frugiperda were the best. However, the pupa weight and fecundity of S. frugiperda fed with G. max and E. indica were significantly lower than those fed with other hosts, efficiency of conversion of digested food (ECD) and efficiency of conversion of ingested food (ECI) were also lower than others. The total phenol content was negatively correlated with the biological and nutritional indexes of $\mathrm{S}$. frugiperda, while the $\mathrm{C} / \mathrm{N}$ content was positively correlated. When fed on different host plants, the biological and nutritional indexes of S. frugiperda were different, but all of them could complete the life cycle. Therefore, in the absence of $\mathrm{Z}$. mays, the S. frugiperda may also harm other host plants, and host plants with high $\mathrm{C} / \mathrm{N}$ content can also with the risk of being infected.
\end{abstract}

\section{Introduction}

The fall armyworm (FAW), Spodoptera frugiperda (Lepidoptera: Noctuidae), is one of the most important pests that has appeared in Asia countries. As early as the 1980s, researchers discovered two S. frugiperda populations preferring corn or rice, respectively (Pashley, 1986). Corn strains prefer corn, sorghum and cotton, while rice strains prefer rice and wild grasses instead (Hay-Roe et al., 2011; Nagoshi et al., 2017). Based on the investigation of $S$. frugiperda found in China, almost all the populations are corn strains (Guo et al., 2018a; Zhang et al., 2019). Although there is a big difference in crop-planting structure between north and south in China, it can still cause great loss and harm (even no grain harvest) due to the wide range of food sources in larvae stage and strong migratory ability in adult stage (Sena et al., 2003; Lima et al., 2010; Jing et al., 2019). In addition crop hosts, some weeds such as Veronica polita, Euphorbiah elioscopial , E. indica, D. sanguinalis are also serious harmed by $S$. frugiperda duo to its high tropism and adaptability (Wang et al., 2020; Yao et al., 2020; Fang et al., 2020). Therefore, there are potential risks to the next crop due to the ability of noctuid transferring to other hosts around corn under edible hosts shortage situation (Guo et al., 2020b).

Under suitable environmental conditions, the growth and development rate, reproduction rate and survival rate of insects are related to the types and quantity of the absorbed nutrients. Balanced and abundant nutrients are conducive to the growth, development and reproduction of insects (Awmack and Leather, 2002; Nosil et al., 2002). Indeed, host nutrition and secondary substances have been reported in Bemisia tabaci (Tsai and Wang, 2001), Frankliniella occidentalis (Brown, 2002), Brown Rice Plant Hopper (Rashid 
et al., 2016),Spodoptera litura (Xu et al., 2010), Papilio polytes (Shobana et al., 2010), and Plutella xylostella (Sarfraz et al., 2009). However, the research on S. frugiperda mainly focuses on prevention and control (Tambo et al., 2019), or genomic and genetic differences studies (Nagoshi and Meagher, 2016; Gouin et al., 2017; Stuhl et al., 2008). Research about the characteristics of $S$. frugiperda on different hosts are reported rarely (Montezano et al., 2018), let alone effects studies between the physical and chemical properties of host and the characteristics of $S$. frugiperda. The shortage of studies in this area seriously limits the determination of damage scope caused by $S$. frugiperda. At the same time, it also limits the prediction of host species that provide the source of insect accumulation.

In this study, five kinds of hosts related to the corn ecological environment were carefully selected according to the cornfield's ecosystem. We assessed the growth development and the nutrient accumulation of immature stages on various host plants and the subsequent adult performance. We have determined the composition of different host plants using the detection method in the national standard. Insect herbivores and their host-plants correlation analysis were also investigated.

\section{Materials and Methods}

\subsection{Insects and Plant Material}

S. frugiperda was collected from Sunji cornfield in Huagang Town, Feixi County, Hefei City, Anhui Province in June 2019. These insects had been fed on a regular artificial diet for more than ten generations. Larvae were reared under controlled conditions of $25 \pm 1,70 \%+-5 \%$ relative humidity $(\mathrm{RH})$, and a photoperiod of $16 \mathrm{~h}: 8 \mathrm{~h}(\mathrm{~L}: \mathrm{D})$. Egg masses laid by females were collected and deposited in box. Then the new larvae from the egg masses were collected for the experimental use and they were fed on an $10 \%$ (w/v) honey-water mixture.

Zea mays, Triticum aestivum, Glycine max ,Digitaria sanguinalis and Eleusine indica were all planted in the agricultural extraction garden of Anhui Agricultural University in Hefei, Anhui Province, China. Host leaves were adopted throughout the experiments.

\subsection{Effects of different host plants on the biological characteristics of Spodoptera frugiperda}

120 newly hatched larvae were reared with each host plant (about $10 \mathrm{~g}$ ) and they were divided into three equal groups in a selected sealed plastic box $(21 \mathrm{~cm}$ in length, $15 \mathrm{~cm}$ in width and $8 \mathrm{~cm}$ in height), whose lids had been punctured with insects needles while bottom padded with filter paper. At the third instar, the larvae were reared separately with 12 -well plates $(2.25 \mathrm{~cm}$ in diameter, $4 \mathrm{~cm}$ in height). In the larval stage, fresh hosts were replaced regularly every day and feces were cleaned up in time, meanwhile, the development period and the survival rate of the larvae were recorded. 15 pupa were randomly selected to weigh their pupae on the second day after pupation. After eclosion, the duration and survival rate of all the pupa were recorded. 15 selected pairs of adults of $S$. frugiperda were reared in a cage (length x width $\mathrm{x}$ height $=70 \mathrm{~cm}$ x $70 \mathrm{~cm} \mathrm{x} 70 \mathrm{~cm}$ ) and fed on $10 \%(\mathrm{w} / \mathrm{v})$ honey-water mixture. Eggs were collected every day to calculate the accurate egg numbers. The environmental controlled conditions of $25+-1,70 \%+-5 \%$ relative humidity $(\mathrm{RH})$, and a photoperiod of $16 \mathrm{~h}: 8 \mathrm{~h}(\mathrm{~L}: \mathrm{D})$.

\subsection{Determination of nutritional indexes of Spodoptera frugiperda feeding on different host plants}

Nutritional indicators were determinated according to the methods decribed previously (Pinto et al., 2019; Scriber and Slansky, 1981) with modifications. Some newly moulted 5th-instar larvae were selected and dried to constant weight at 85 to obtain the average dry weight. The others were fed by a certain number of different hosts (dry weight was measured previously). The remaining food was replaced by fresh hosts and collected carefully every day, then it was dried to constant weight at 85 . The excrement was also collected and dried with the same procedure. At the end of 6th-instar (feeding and defecation were stopped), the 
average dry weight were also measured.

\author{
Relative Growth Rate $(\mathrm{RGR})=\mathrm{G} /(\mathrm{B} \times \mathrm{T})$ \\ Relative Consumption Rate $(\mathrm{RCR})=\mathrm{I} /(\mathrm{B} \times \mathrm{T})$ \\ Approximate Digestibility $(\mathrm{AD})=(\mathrm{I}-\mathrm{F}) / \mathrm{I} \times 100 \%$ \\ Efficiency of Conversion of Digested food $(\mathrm{ECD})=\mathrm{G} /(\mathrm{I}-\mathrm{F}) \times 100 \%$ \\ Efficiency of Conversion of Ingested food $(\mathrm{ECI})=\mathrm{G} / \mathrm{I} \times 100 \%$
}

$\mathrm{T}$ (day) is the duration from newly moulted 5th-instar larvae to the end of 6th-instar larvae. $\mathrm{G}(\mathrm{g})$ is the increased dry weight of larvae during T. I $(\mathrm{g})$ is the dry weight of food consumed during T. F (g) is the dry weight of the excreta during T. B $(\mathrm{g})$ is the mean weight of larvae during T.

The environmental conditions are the same as above.

\title{
2.4. Determination of nutrients and secondary substances in different host plants
}

Soluble sugar: $100 \mathrm{mg}$ grated host tissue was added to $10 \mathrm{~mL}$ ethanol in a volumetric flask, then the volumetric flask was placed in $80 \sim 85$ water bath with stirring for 30 min. Afterwards, the solution was cooled down and centrifuged for 10 minutes at $5000 \mathrm{r} / \mathrm{min}$. Then the supernatant was transferred to a beaker. The beaker was placed in 85 water bath to evaporate the remanent ethanol, and then it was adjusted to 50 $\mathrm{mL}$ with distilled water. Ultimately, the content of soluble sugar in the extract was determined by anthrone colorimetry.

Protein: $2 \mathrm{~g}$ sample, $0.4 \mathrm{~g}$ copper sulfate, $6 \mathrm{~g}$ potassium sulphate, and $20 \mathrm{~mL}$ sulphuric acid were added into a dry $500 \mathrm{~mL}$ Kjeldahl flasks in turn. After shaking gently, the Kjeldahl flasks was slanted at 45-degree angle on asbestos net with a small funnel placed at mouth of the bottle. Then the bottle was carefully heated. When the content was completely carbonized (no foam was produced), the heat should be further increased to keep the liquid boiling slightly until the liquid changed to be clear blue-green. After another continuous heating for $0.5 \mathrm{~h} \sim 1 \mathrm{~h}$, the Kjeldahl flasks was removed out and cooled to room temperature. Then the solution was transferred to a $100 \mathrm{~mL}$ volumetric flask, meanwhile, a small amount of distilled water was used to wash the Kjeldahl flasks several times with the lotion transferred into the $100 \mathrm{~mL}$ volumetric flask, too. Finally, distilled water was added to the scale line and the solution was mixed thoroughly. The protein content was determined by Automatic Kjeldahl nitrogen analyzer.

Total amino acids: $2 \mathrm{~mL}$ hydrochloric acid $(6 \mathrm{~mol} / \mathrm{L})$ was added into homogenate $(2 \mathrm{~g})$ and the well mixed solution was added to $10 \mathrm{~mL}$ by hydrochloric acid in a hydrolysate tube. 3 drops phenol were added into the solution and the hydrolysate tube was put into refrigerant for $3 \sim 5$ minutes. The tube was then connected with the suction pipe of a vacuum pump for vacuumizing, afterwards, it was filled in with nitrogen (repeating for 3 times) for sealing. The sealed hydrolytic bottle was put into an electric blast incubator at $110 \pm 1$ for $22 \mathrm{~h}$ and it was taken out and cooled to room temperature after heating. The mixed solution was filtered and the filtrate was transferred into a $50 \mathrm{~mL}$ volumetric flask to bring to volume by distilled water. $1 \mathrm{~mL}$ liquid from the volumetric flask was dried and steamed in a $15 \mathrm{~mL}$ test tube, and then it was dissolved by 2 $\mathrm{mL}$ sodium citrate buffer solution. After being passed through a $0.22 \mu \mathrm{m}$ filter membrane, the solution was transferred to an amino acid automatic analyzer (JJG1046-2011) injection bottle for accurate determination.

$\mathrm{C} / \mathrm{N}$ ratio: $0.1 \mathrm{~g}$ host sample, $0.1 \mathrm{~g}$ silver sulfate powder, $5 \mathrm{~mL}$ potassium dichromate standard solution $(0.8 \mathrm{~mol} / \mathrm{L})$ and $5 \mathrm{~mL}$ concentrated sulfuric acid were added into a test tube. The $\mathrm{C} / \mathrm{N}$ ratio results were obtained through digestion and titration procedures. Each samples were repeated for 3 times. 
Water: $10 \mathrm{~g}$ leaves of each host were weighed and dried in a drying box at 85 . After drying, the mass of the corresponding dried leaves was weighed by an electronic balance to calculate the water content of the leaves. Repeat this process for 3 times.

Total flavonoids: $1 \mathrm{~g}$ sample and $30 \mathrm{~mL}$ anhydrous ethanol were added into a $100 \mathrm{~mL}$ conical flask for extraction in an ultrasonic cleaner $(1 \mathrm{~h})$. After cooling to room temperature, the solution was filtered to a $50 \mathrm{~mL}$ volumetric flask and bought to volume by anhydrous ethanol. Sample absorbance at $420 \mathrm{~nm}$ was measured, and the obtained standard curve was used to calculate the total flavonoid contents.

Tannin: $2 \mathrm{~g}$ homogenized sample and $80 \mathrm{~mL}$ distilled water were added into a $100 \mathrm{~mL}$ volumetric flask in boiling water to extract tannin for 30 minutes. After being cooled to room temperature, brought it to marked volume by distilled water. $2 \mathrm{~mL}$ solution was sucked into a centrifuge tube for centrifugation at 8000 $\mathrm{r} / \mathrm{min}$ (4 minutes). $1 \mathrm{~mL}$ supernatant (after centrifugation), $5 \mathrm{~mL}$ water, $1 \mathrm{~mL}$ mixture solution of sodium tungstate and sodium molybdate, and $3 \mathrm{~mL}$ sodium carbonate were mixed for color reaction (2 hours). After this step, sample absorbance was measured at $765 \mathrm{~nm}$ and the obtained standard curve was used to calculate the tannin content.

Total phenol: $0.5 \mathrm{~g}$ sample was milled to slurry with $3 \mathrm{~mL} 95 \%$ ethanol and filtered, then the filtrate was transferred to a $25 \mathrm{~mL}$ volumetric flask and brought to volume by $95 \%$ ethanol. $2 \mathrm{~mL}$ sample solution and $2 \mathrm{~mL}$ folin were mixed and shaked for 3 minutes in $10 \mathrm{~mL}$ test tube, then $2 \mathrm{~mL} 10 \%$ sodium carbonate was added. After vibrating and standing ( 1 hour), the mixed solution was measured by colourimetric absorbance at $700 \mathrm{~nm}$ and the total phenol content was calculated from the standard curve.

All the above samples were fresh host leaves.

\subsection{Data analysis}

Excel 2003 was used to conduct statistics on the original data. SPSS 23.0 was used to analyze the contents of different host components, nutritional indexes and biological indexes of $S$. frugiperdafeeding on different host plants by one-way analysis of variance (one-way ANOVA) and the resukts were tested by Tukey's HSD $(P<0.05)$. The relationship between chemical components of different hosts and growth and nutritional indicators of $S$. frugiper da was also analyzed by SPSS 23.0 with pearson correlation coefficient.

\section{Results}

\subsection{Biological characteristics of Spodoptera frugiperdafeeding on different host plants}

As shown in Table 1, the survival rates of low-instar larvae (larva of instar 1 to 3) and older-instar larvae (larva of instar 4 to 6 ) of $S$. frugiperda $(99.17 \%$ and $81.52 \%$, respectively) fed on $Z$. mays are much higher than larvae fed on other hosts, while larvae fed on $G$. max have the lowest survival rate ( $85.83 \%$ and $64.06 \%$ ). The developmental durations of older-instar larvae fed on E. indica (10.43 days) is the longest, while low-instar larvae fed on $Z$. mays have the shortest developmental durations (6.22 days).

Table 1 shows that the pupal weight of $S$. frugiperda fed onZ.mays in larval stage is heaviest, up to 296.67 $\mathrm{mg}$, followed by larvae fed on T. aestivum $(285.33 \mathrm{mg})$. Larvae fed on $G$. max has the lowest pupal weight $(257 \mathrm{mg})$. Egg-production amount (representation of fecundity) of S. frugiperda fed onZ.mays in the larval stage has the largest number, as much as $1308 \mathrm{eggs}$, while the minimum number (994 eggs) of $S$. frugiperdafed on E. indica in larval stage.

Based on these results, it can be concluded that biological characteristics of $S$. frugiperda fed on different host plants in larval stage had significant difference.

\subsection{Nutritional indexes of Spodoptera frugiperda feeding on different host plants}

The nutritional indexes in Table 2 reveals that the RGR $(12.80 \mathrm{mg} / \mathrm{mg} / \mathrm{d})$, ECD (13.43\%), and ECI (6.82\%) of $S$. frugiperda larvae fed onZ. mays are much higher than larvae fed on other hosts. The RCR $(2.44$ $\mathrm{mg} / \mathrm{mg} / \mathrm{d}$ ) of $S$. frugiperda larvae fed on E. indica were significantly higher than larvae fed on other hosts. 
As shown in Table 2, the AD of $S$. frugiperda fed on different host plants in larval stage had no significant difference.

\subsection{Nutrient composition and secondary substance content of different host plants}

Fig. 1 shows that there are some differences in the nutrient contents and the secondary substances among different host-plants (all $P$ values $<0.05$ ). The soluble sugar (Fig. 1A), protein (Fig. 1B), total amino acids (Fig. 1C), total phenol (Fig. 1D) contents of Z.mays are lowest, while those of G. max are highest. The total flavonoid (Fig. 1E), tannin (Fig. 1F) contents of $E$. indica are lowest, while those of G. max are highest. As shown in Fig. 1G, the $\mathrm{C} / \mathrm{N}$ content is higher in Z. mays than other hosts, while it is much lower in $D$.sanguinalis. However, the water contents for all hosts display no significant differences (Fig. 1H).

\subsection{Correlation analysis between host plant andSpodoptera frugiperda}

As shown in Table 3, the survival rate of low-instar larvae and older-instar larvae are mainly affected by the protein $(\mathrm{R}=-0.862$ and $\mathrm{R}=-0.793)$ (all $P$ values $<0.01)$, total amino acids $(\mathrm{R}=-0.773$ and $\mathrm{R}=-0.651$ ) (all $P$ values $<0.01)$, total phenols $(\mathrm{R}=-0.943$ and $\mathrm{R}=-0.916)$ (all $P$ values $<0.01$ ), otal flavonoids $(\mathrm{R}=$ -0.706 and $\mathrm{R}=-0.643)$ (all $P$ values $<0.01), \mathrm{C} / \mathrm{N}(\mathrm{R}=0.516$ and $\mathrm{R}=0.605)$ (all $P$ values $<0.05$ ), and water $(\mathrm{R}=0.801$ and $\mathrm{R}=0.847$ ) (all $P$ values $<0.01$ ) in the host plants. In addition, soluble sugar content has a significant effect on the survival rate of low-instar larvae $(\mathrm{R}=-0.634, P<0.05)$ but the survival rate of older-instar larvae is not affected by it obviously. The developmental period of larvae (low-instar and older-instar) is negatively correlated with $\mathrm{C} / \mathrm{N}(\mathrm{R}=-0.795$ and $\mathrm{R}=-0.701)$ (all $P$ values $<0.01$ ) but positively correlated with total phenol content $(\mathrm{R}=0.560$ and $\mathrm{R}=0.707)(P<0.05$ and $P<0.01$, respectively). Pupa weight is negatively correlated with protein $(\mathrm{R}=-0.531, P<0.05)$, total amino acid $(\mathrm{R}=-0.605, P<0.05)$ and total phenol $(\mathrm{R}=-0.758, P<0.01)$; and it is positively correlated with $\mathrm{C} / \mathrm{N}$ $(\mathrm{R}=0.776, P<0.01)$. The fecundity is mainly negatively correlated with the total amino acid content $(\mathrm{R}$ $=-570, P<0.05)$ of the host, and positively correlated with $\mathrm{C} / \mathrm{N}(\mathrm{R}=0.887, P<0.01)$.

According to the data in Table 4, the RGR of $S$. frugiperda has remarkably positive correlation with water $(\mathrm{R}=0.545, P<0.01)$ and $\mathrm{C} / \mathrm{N}(\mathrm{R}=0.746, P<0.01)$. The RGR also has significant negative correlation with protein $(\mathrm{R}=-0.671, P<0.01)$, total amino acids $(\mathrm{R}=-0.887, P<0.01)$, total phenols $(\mathrm{R}=-0.889$, $P<0.01)$ and total flavonoids $(\mathrm{R}=-0.716, P<0.01)$. The RCR is prominently positively correlated with $\mathrm{C} / \mathrm{N}(\mathrm{R}=0.707, P<0.01)$ and $\mathrm{AD}$ is positively correlated with water content $(\mathrm{R}=0.558, P<0.05)$. ECD and ECI are significantly positively correlated with $\mathrm{C} / \mathrm{N}(\mathrm{R}=0.875$ and $\mathrm{R}=0.874$, respectively) (all $P$ values $<0.01)$, but negatively correlated with total amino acids $(\mathrm{R}=-0.801$ and $\mathrm{R}=-0.805$, respectively) (all $P$ values $<0.01)$ and total phenols $(\mathrm{R}=-0.728$ and $\mathrm{R}=-0.749$, respectively) (all $P$ values $<0.01$ ).

\section{Discussion}

As the multi-feeding insects, S. frugiperda will produce different host plants adaptability when feeding on different hosts (Naseri et al., 2009; Razmjou et al., 2014; Guo et al., 2020b). For the most species of insects, developmental stage of larvae, pupa weight, and number of eggs laid by female can be used to judge the best host plants for insects as a criteria (Greenberg et al., 2002). In this study, after fed on Z. mays, survival rate and fecundity of $S$. frugiperda are highest, and the development period were the shortest. Followed by fed on $T$. aestivum, however, the survival rate of the low-instar larvae and older-instar larvae of $S$. frugiperda were lowest when fed on $G$. max. In addition, the development period of the older-instar larvae fed on $G$. max and E. indica were relatively longer, and the pupal weight and fecundity were lower than fed on other hosts. Some studies have shown that when insects fed on poor-quality hosts, they have to eat more hosts to remove the effect of the changes in host species (Pinto et al., 2019). In the present study, S. frugiperda has a higher RGR on E. indica, but the ECI is lower relatively. In contrast, S. frugiperda fed on Z. mays has the lowest RCR and the highest ECI. Thus, combining the effects of fed on five hosts in this study on the growth and development of $S$. frugiperda, Z. mays were optimal host and E. indica is the least suitable host for S. frugiperda .

There are different nutrient and secondary substance content with different hosts (Wilson et al., 2019). 
In general, the insects fed on high-quality hosts have shorter duration of development, lower consumption rate, higher growth rate, and higher food processing efficiency (Awmack and Leather, 2002; Vellau et al., 2013; Cunha et al., 2008). According to the correlation analysis of the host phytochemical content with the biological and nutritional indexes of $S$. frugiperda, we find that $\mathrm{C} / \mathrm{N}$ plays an active role in the growth of S. frugiperda . This is consistent with the conclusion obtained by Holopainen (2002). Phenolic substances, one of the main chemical defense substances in the host plants (Awmack and Leather, 2002; Steinbauer, 2018), have a significant negative correlation to the growth and development and nutritional indexes of $S$. frugiperda. Besides, the total flavonoid content affects the survival rate of the low-instar and older-instar larvae and RGR of $S$. frugiperda. There is no significant correlation between the tannin content and the entire growth and development of $S$. frugiperda. In other related studies, it has been found that the protein and amino acid content of plants can promote the growth and development of insects (Dai et al., 2020), but the results obtained in this study are contrary to the results. This might be caused by other factors in the feeding process. There is a complex dynamic relationship between the content of phytochemicals and the herbivorous insects (Steinbauer, 2018). The nutrient content and secondary metabolite content of the host plant will change the feeding behavior and feeding response of insects. Therefore, it is impossible to make a broad generalization of the effect of a single host phytochemical on herbivorous insects, and the quality of the host plant is also affected by the physical properties (hardness, surface hair density and shape), which need to be further studied.

\section{Conclusion}

In this study, although the adaptability to D. sanguinalis , G. max and E. indica is not as good as that to Z. mays and T. aestivum, S. frugiperda can still complete its life cycle after feeding. Therefore, it is necessary to pay attention not only to crops, but also to the species and quantity of the surrounding weeds in the control process of $S$. frugiperda. Besides, it is found in this study that the higher $\mathrm{C} / \mathrm{N}$ content, the more favorable effect for $S$. frugiperda. It has also been reported that the level of fertilization will affect the $\mathrm{C} / \mathrm{N}$ expression in plants in other related literatures (Ibrahim et al., 2011; Deng et al., 2020). Therefore, the control of $S$. frugiperda can also be carried out by adjusting the amount of fertilizer.

\section{Acknowledgments}

This research was supported by the Major Special Science and Technology Project of Anhui Province, China (Grant No. 201903a06020027), Key Program of Anhui Province Tobacco Corporation, China (Grant No. 20170551024), and Key Project for Academic and Technical Leader Candidate of Anhui Province, China (Grant No. 2019H238).

\section{Disclosure of competing interest}

The authors declare that they have no conflict of interest.

\section{Data Accessibility}

Effects and correlation analysis of different host-plant components on physiological indexes in Spodoptera frugiperda: Dryad doi: 10.5061/dryad.t4b8gtj22.

\section{References}

Awmack, C. S., \& Leather S. R. (2002). Host plant quality and fecundity in herbivorous insects.Annual Review of Entomology , 47, 817-844.

Brown, A. S. S., Simmonds, M. S. J., \& Blaney, W. M. (2002). Relationship between nutritional composition of plant species and infestation levels of thrips. Journal of Chemical Ecology , 28, 2399-2409.

Cunha, U. S., Martins, J. F. S., Porto, M. P., Garcia, M. S., Bernardi, O., Trecha, C. O., Bernardi, D., Jardim, E. O., \& Back, E. C. U. (2008). Resistência de genótipos de milho para cultivo em várzeas subtropicais à lagarta-do-cartucho Spodoptera frugiperda. Ciência Rural , 38, 1125-1128. 
Dai, Q. X., Li, Z. Y., Tian, Y. J., Zhang, Z. F., Wang, L., Lu, Y. Y., Li, Y. Z., \& Chen, K. W. (2020). Effects of different corn varieties on development and reproduction of Spodoptera frugiperda. Journal of Applied Ecology , 31, 3273-3281.

Deng, X. F., Ma, W. Z., Ren, Z. Q., Zhang, M. H., Grieneisen, M. L., Chen, X. J., Fei, X. F., Qin, F. J., Zhan, Y., \& Lv, X. N. (2020). Spatial and temporal trends of soil total nitrogen and C/N ratio for croplands of East China. Geoderma, 361, 114035.

Fang, M., Yao, L., Tang, Q. F., Li, G. T., \& Jiang, X. C. (2020). Adaptability of Spodoptera frugiperda to several weeds. Journal of Plant Protection , 47, 1055-1061. (in Chinese)

Gouin, A., Bretaudeau, A., Nam, K., Gimenez, S., Aury, J. M., Duvic, B., Hilliou, F., Durand, N., Montagné, N., Darboux, I., Kuwar, S., et al . (2017). Two genomes of highly polyphagous lepidopteran pests (Spodoptera frugiperda, Noctuidae) with different host-plant ranges. Scientific Reports , 7, 11816.

Greenberg, S. M., Sappington, T. W., Sétamou, M., \& Liu, T. X. (2002). Beet armyworm (Lepidoptera: Noctuidae) host plant preferences for oviposition. Environmental Entomology, 31, 142-148.

Guo, J. F., Zhao, J. Z., He, K. L., Zhang, F., \& Wang, Z. Y. (2018a). Potential invasion of the crop-devastating insect pest fall armywormSpodoptera frugiperda to China. Plant Protection , 44, 1-10. (in Chinese)

Guo, J. F., Zhang, M. D., Gao, Z. P., Wang, D. J., He, K. L., \& Wang, Z. Y. (2020b). Comparison of larval performance and oviposition preference of Spodoptera frugiperda among three host plants: potential risks to potato and tobacco crops. Insect science, https: //doi:10.1111/1744-7917-12830.

Hay-Roe, M, M., Reagher, R. L., \& Nagoshi, R. N. (2011). Effects of cyanogenic plants on fitness in two host strains of the fall armyworm (Spodoptera frugiperda ). Journal of Chemical Ecology , 37, 1314-1322.

Holopainen, J. K. (2002). The nutritional ecology of maturation in a carnivorous insect.Entomologia Experimentalis et Applicata, 104, 137-142.

Ibrahim, M. H., Jaafar, H. Z. E., Rahmat, A., \& Rahman, Z. A. (2011). Effects of nitrogen fertilization on synthesis of primary and secondary metabolites in three varieties ofKacip Fatimah (Labisia Pumila Blume). International Journal of Molecular Sciences , 12, 5238-5254.

Jing, D. P., Guo, J. F., Jiang, Y. Y., Zhao, J. Z., Sethi, A., He, K. L., \& Wang, Z. Y. (2019). Initial detections and spread of invasiveSpodoptera frugiperda in China and comparisons with other noctuid larvae in cornfields using molecular techniques. Insect Science, 27, 1-11.

Lima, M. S., Silva, P. S. L., Oliveira, O. F., Silva, K. M. B., \& Freitas, F. C. L. (2010). Maize yield response to weed and fall armyworm controls. Planta Daninha , 28, 103-111.

Montezano, D. G., Specht, A., Sosa-Gmez, D. R., Roque-Specht, V. F., Sousa-Silva, J. C., Paula-Moraes, S. V., Peterson, J. A., \& Hunt, T. E.. (2018). Host plants of Spodoptera frugiperda (Lepidoptera: Noctuidae) in the Americas. African Entomology , 26, 286-300.

Nagoshi, R. N., Koffi, D., Agboka, K., Tounou, K. A., Banerjee, R., Jurat-Fuentes, J. L., \& Meagher, R. L. (2017). Comparative molecular analyses of invasive fall armyworm in togo reveal strong similarities to populations from the eastern United States and the Greater Antilles. PLoS ONE , 12, e0181982.

Nagoshi, R. N., \& Meagher, R. L. (2016). Using intron sequence comparisons in the triose-phosphate isomerase gene to study the divergence of the fall armyworm host strains. Insect Molecular Biology , 25, 324-337.

Naseri, B., Fathipour, Y., Moharramipour, S., \& Hosseininaveh, V. (2009). Comparative life history and fecundity of Helicoverpa armigera (hubner) (lepidoptera: noctuidae) on different soybean varieties. Entomological ence , 12, 147-154.

Nosil, P., Crespi, B. J., \& Sandoval, C. P. (2002). Host-plant adaptation drives the parallel evolution of reproductive isolation.Nature, 417, 440-443. 
Pashley, D. P. (1986). Host-associated genetic differentiation in fall armyworm (Lepidoptera: Noctuidae): a sibling speciescomplex? Annals of Entomological Society of America , 79, 898-904.

Pinto, J. R. L., Torres, A. F., Truzi, C. C., Vieira, N. F., Vacari, A. M., \& Bortoli, S. A. (2019). Artificial corn-based diet for rearingSpodoptera frugiperda (Lepidoptera: Noctuidae). Journal of Insect Science , 19, $1-8$.

Rashid, M. M., Jahan, M., \& Islam, K. S. (2016). Response of adult Brown Planthoppernilaparvata lugens (Stal) to rice nutrient management. Neotropical Entomology , 45, 588-596.

Razmjou, J., Naseri, B., \& Hemati, S. A. (2014). Comparative performance of the cotton bollworm, Helicoverpa armigera (Hubner) (Lepidoptera: Noctuidae) on various host plants. Journal of Pest Science , 87, 29-37.

Sarfraz, R. M., Dosdall, L. M., \& Keddie, A. B. (2009). Bottom-up effects of host plant nutritional quality on Plutella xylostella (Lepidoptera: Plutellidae) and top-down effects of herbivore attack on plant compensatory ability.European Journal of Entomology , 106, 583-594.

Scriber, J. M., \& Slansky, J. F. (1981). The nutritional ecology of immature insects. Annual Review of Entomology , 26, 183-211.

Sena, D. G., Pinto, F. A. C., Queriroz, D. M., \& Viana, P. A. (2003). Fall armyworm damaged maize plant identification using digital images.Biosystems Engineering , 85, 449-454.

Shobana, K., Murugan, K., \& Kumar, A. N. (2010). Influence of host plants on feeding, growth and reproduction of Papilio polytes (The common mormon).Journal of Insect Physiology , 56, 1065-1070.

Steinbauer, M. J. (2018). Role of phytochemistry in insect nutrition.Austral Entomology, 57, 214-219.

Stuhl, C. J., Meagher, R. L., \& Nagoshi, R. N. (2008). Genetic variation in neonate behavior of fall armyworm (Lepidoptera : Noctuidae). Florida Entomologist, 91, 151-158.

Tambo, J. A., Day, R. K., Lamontagne-Godwin, J., Silvestri, S., Beseh, P. K., Oppong-Mensah, B., Phiri, N. A., \& Matimelo, M. (2019). Tackling fall armyworm (Spodoptera frugiperda) outbreak in Africa: an analysis of farmers' control actions. International Journal of Pest Management , 66, 298-310.

Tsai, J. H., \& Wang, J. J. (2001). Effects of host plants on biology and life table parameters of Aphis spiraecola (Homoptera: Aphididae). Environmental Entomology , 30, 44-50.

Vellau, H., Sandre, S. L., \& Tammaru, T. (2013). Effect of host species on larval growth differs between instars: The case of a geometrid moth (Lepidoptera: Geometridae). European Journal of Entomology, 110, 599-604.

Wang, W. W., He, P. Y., Zang, Y. Y., Liu, T. X., Jing, X. F., \& Zhang, S. Z. (2020). The population growth of Spodoptera frugiperda on six cash crop species and implications for its occurrence and damage potential in China. Insects, 11, 639.

Wilson, J. K., Ruiz, L., Duarte, J., \& Davidowitz, G. (2019). The nutritional landscape of host plants for a specialist insect herbivore.Ecology and Evolution , 00, 1-10.

Xu, M., Pang, Y. H., Wang, H. T., Li, Q. L., \& Liu, T. X. (2010). Effects of four host plants on biology and food utilization of the cutworm, Spodoptera litura . Journal of Insect Science, 10, 1-14.

Yao, L., Fang, M., Li, X. M., Li, G. T., \& Tang, Q. F. (2020). Oviposition and feeding selectivity of Spodoptera frugiperda to three weeds. Plant Protection , 46, 181-184. (in Chinese)

Zhang, L., Jin, M. H., Zhang, D. D., Jiang, Y. Y., Liu, J., Wu, K. M., \& Xiao, Y. T. (2019). Molecular identification of invasive fall armyworm Spodoptera frugiperda in Yunnan province. Plant Protection, 45, 19-24. (in Chinese) 
Table 1 Survival rates, developmental durations, pupa weight and fecundity of Spodoptera frugiperda on Zea mays, Triticum aestivum, Glycine max, Digitaria sanguinalis and Eleusine indica.

\begin{tabular}{|c|c|c|c|c|c|}
\hline Indicators & $\begin{array}{l}\text { Zea mays (mean } \\
\pm \mathrm{SE} \text { ) }\end{array}$ & $\begin{array}{l}\text { Triticum } \\
\text { aestivum (mean } \\
\pm \mathrm{SE} \text { ) }\end{array}$ & $\begin{array}{l}\text { Digitaria } \\
\text { sanguinalis } \\
(\text { mean } \pm \mathrm{SE})\end{array}$ & $\begin{array}{l}\text { Glycine max } \\
(\text { mean } \pm \mathrm{SE})\end{array}$ & $\begin{array}{l}\text { Eleusine indica } \\
\text { (mean } \pm \mathrm{SE})\end{array}$ \\
\hline $\begin{array}{l}\text { Survival rate } \\
\text { of low-instar } \\
\text { larvae } / \%\end{array}$ & $99.17 \pm 0.83 \mathrm{a}$ & $93.33 \pm 0.83 \mathrm{~b}$ & $92.50 \pm 1.44 \mathrm{~b}$ & $85.83 \pm 0.83 \mathrm{c}$ & $93.33 \pm 0.83 \mathrm{~b}$ \\
\hline $\begin{array}{l}\text { Survival rate } \\
\text { of older-instar } \\
\text { larvae /\% }\end{array}$ & $81.52 \pm 0.77 \mathrm{a}$ & $77.69 \pm 0.69 \mathrm{~b}$ & $73.88 \pm 0.59 \mathrm{c}$ & $64.06 \pm 1.19 \mathrm{~d}$ & $72.31 \pm 1.04 \mathrm{c}$ \\
\hline $\begin{array}{l}\text { Development } \\
\text { period of } \\
\text { low-instar } \\
\text { larvae / days }\end{array}$ & $6.22 \pm 0.44 \mathrm{~d}$ & $6.29 \pm 0.01 \mathrm{~d}$ & $6.53 \pm 0.05 \mathrm{c}$ & $6.68 \pm 0.06 \mathrm{~b}$ & $6.84 \pm 0.05 \mathrm{a}$ \\
\hline $\begin{array}{l}\text { Development } \\
\text { period of } \\
\text { older-instar } \\
\text { larvae / days }\end{array}$ & $9.20 \pm 0.17 \mathrm{c}$ & $9.62 \pm 0.05 \mathrm{bc}$ & $9.80 \pm 0.03 \mathrm{~b}$ & $10.40 \pm 0.12 \mathrm{a}$ & $10.43 \pm 0.16 \mathrm{a}$ \\
\hline $\begin{array}{l}\text { Pupa weight } \\
/ \mathrm{mg}\end{array}$ & $\begin{array}{l}296.67 \pm 2.96 \\
\mathrm{a}\end{array}$ & $\begin{array}{l}285.33 \pm 3.18 \\
b\end{array}$ & $\begin{array}{l}273.33 \pm 1.20 \\
\mathrm{c}\end{array}$ & $\begin{array}{l}257.00 \pm 5.03 \\
\mathrm{~d}\end{array}$ & $\begin{array}{l}259.67 \pm 4.10 \\
\mathrm{~d}\end{array}$ \\
\hline $\begin{array}{l}\text { Fecundity } \\
\text { /eggs }\end{array}$ & $\begin{array}{l}1308.00 \pm 6.35 \\
\mathrm{a}\end{array}$ & $\begin{array}{l}1204.67 \pm 9.24 \\
\mathrm{~b}\end{array}$ & $\begin{array}{l}1119.33 \pm 8.99 \\
\mathrm{c}\end{array}$ & $\begin{array}{l}1059.33 \pm \\
26.97 \mathrm{~d}\end{array}$ & $\begin{array}{l}994.00 \pm 19.40 \\
d\end{array}$ \\
\hline
\end{tabular}

low-instar larvae : larva of instar 1 to 3 ;

older-instar larvae : larva of instar 4 to 6.

Fecundity : egg-production amount.

The data in the table are "mean +- SE", different lowercase letters following data in the same row indicate significant difference $(P<0.05)$.

Table 2 The nutritional indexes determination of Spodoptera frugiperda on Zea mays, Triticum aestivum, Glycine max, Digitaria sanguinalis and

Eleusine indica.

\begin{tabular}{llllll}
\hline Zea mays (mean & $\begin{array}{l}\text { Triticum } \\
\text { aestivum } \\
\pm \mathrm{SE} \text { ) }\end{array}$ & $\begin{array}{l}\text { Digitaria } \\
\text { sanguinalis } \\
\text { (mean } \pm \mathrm{SE})\end{array}$ & $\begin{array}{l}\text { Glycine max } \\
\text { (mean } \pm \mathrm{SE})\end{array}$ & $\begin{array}{l}\text { Eleusine indica } \\
\text { (mean } \pm \mathrm{SE} \text { ) }\end{array}$ \\
\hline $\begin{array}{l}\mathrm{RGR} \\
/ \mathrm{mg} / \mathrm{mg} / \mathrm{d}\end{array}$ & $12.80 \pm 0.19 \mathrm{a}$ & $11.16 \pm 0.28 \mathrm{~b}$ & $\begin{array}{l}10.38 \pm 0.02 \\
\mathrm{bc}\end{array}$ & $9.96 \pm 0.24 \mathrm{c}$ & $10.95 \pm 0.34 \mathrm{~b}$ \\
$\mathrm{RCR}$ & $1.88 \pm 0.01 \mathrm{c}$ & $2.07 \pm 0.06 \mathrm{bc}$ & $2.09 \pm 0.01 \mathrm{bc}$ & $2.12 \pm 0.05 \mathrm{~b}$ & $2.44 \pm 0.08 \mathrm{a}$ \\
$/ \mathrm{mg} / \mathrm{mg} / \mathrm{d}$ & & & & \\
$\mathrm{AD} / \%$ & $50.78 \pm 0.31 \mathrm{a}$ & $50.88 \pm 0.43 \mathrm{a}$ & $51.00 \pm 0.34 \mathrm{a}$ & $50.02 \pm 0.25 \mathrm{a}$ & $50.56 \pm 0.36 \mathrm{a}$ \\
$\mathrm{ECD} / \%$ & $13.43 \pm 0.20 \mathrm{a}$ & $10.63 \pm 0.58 \mathrm{~b}$ & $9.73 \pm 0.05 \mathrm{bc}$ & $9.42 \pm 0.14 \mathrm{c}$ & $8.88 \pm 0.05 \mathrm{c}$ \\
$\mathrm{ECI} / \%$ & $6.82 \pm 0.06 \mathrm{a}$ & $5.40 \pm 0.25 \mathrm{~b}$ & $4.96 \pm 0.01 \mathrm{c}$ & $4.71 \pm 0.06 \mathrm{~cd}$ & $4.49 \pm 0.05 \mathrm{~d}$ \\
\hline
\end{tabular}

RGR: Relative Growth Rate; 
RCR: Relative Consumption Rate;

AD: Approximate Digestibility;

ECD: Efficiency of Conversion of Digested food;

ECI: Efficiency of Conversion of Ingested food.

The data in the table are "mean $\pm \mathrm{SE}$ ", different lowercase letters following data in the same row indicate significant difference $(P<0.05)$.

Table 3 Correlation between analysis from the phytochemical content of different hosts and biological indicators of Spodoptera frugiperda after feeding on different hosts using pearson correlation coefficient.

\begin{tabular}{llllll}
\hline Indicators & Soluble sugar & Protein & Total amino acids & Total phenols & Total flav \\
\hline Survival rate of low-instar larvae /\% & $-0.634^{*}$ & $-0.862^{* *}$ & $-0.773^{* *}$ & $-0.943^{* *}$ & $-0.706^{* *}$ \\
Survival rate of older-instar larvae /\% & -0.457 & $-0.793^{* *}$ & $-0.651^{* *}$ & $-0.916^{* *}$ & $-0.643^{* *}$ \\
Development period of low-instar larvae /days & -0.023 & 0.289 & 0.438 & $0.560^{*}$ & 0.190 \\
Development period of older-instar larvae/days & -0.272 & $0.522^{*}$ & $0.559^{*}$ & $0.707^{* *}$ & 0.281 \\
Pupa weight /mg & -0.235 & $-0.531^{*}$ & $-0.605^{*}$ & $-0.758^{* *}$ & -0.400 \\
Fecundity /eggs & -0.003 & -0.217 & $-0.570^{*}$ & -0.531 & -0.149 \\
\hline
\end{tabular}

low-instar larvae : larva of instar 1 to 3 ;

older-instar larvae : larva of instar 4 to 6 .

Fecundity : egg-production amount.

The data in the table are correlation coefficient, "* =significant at $P<0.05,{ }^{* *}=$ significant at $P<0.01 "$.

Table 4 Correlation between analysis from the phytochemical content of different hosts and nutrition indicators of Spodoptera frugiperda after feeding on different hosts using pearson correlation coefficient.

\begin{tabular}{lllllllll}
\hline Indicators & Soluble sugar & Protein & Total amino acids & Total phenols & Total flavonoids & Tannin & C/N & W \\
\hline RGR /mg/mg/d & -0.445 & $-0.671^{* *}$ & $-0.887^{* *}$ & $-0.889^{* *}$ & $-0.716^{* *}$ & -0.407 & $0.746^{* *}$ & 0. \\
RCR /mg/mg/d & -0.021 & 0.062 & -0.375 & 0.259 & -0.146 & -0.483 & $-0.707^{* *}$ & 0. \\
$\mathrm{AD} / \%$ & -0.277 & -0.428 & -0.117 & -0.373 & -0.159 & 0.007 & 0.057 & 0. \\
ECD /\% & -0.279 & -0.435 & $-0.801^{* *}$ & $-0.728^{* *}$ & -0.394 & -0.026 & $0.875^{* *}$ & 0. \\
ECI /\% & -0.298 & -0.480 & $-0.805^{* *}$ & $-0.749^{* *}$ & -0.403 & -0.021 & $0.874^{* *}$ & 0. \\
\hline
\end{tabular}

RGR: Relative Growth Rate;

RCR: Relative Consumption Rate;

AD: Approximate Digestibility;

ECD: Efficiency of Conversion of Digested food;

ECI: Efficiency of Conversion of Ingested food.

The data in the table are correlation coefficient, "* =significant at $P<0.05,{ }^{* *}=$ significant at $P<0.01$ ".

Fig. 1 Mean \pm SE numbers of phytochemical content of different hosts (Zea mays, Triticum aestivum, Glycine max ,Digitaria sanguinalis and Eleusine indica) (A) Soluble sugar (B) Protein (C) Total amino acids (D) Total phenols (E) Total flavonoids (F) Tannin (G) C/N (H) Water. Different lowercase letters indicate means are significantly different at $P<0.05$. 

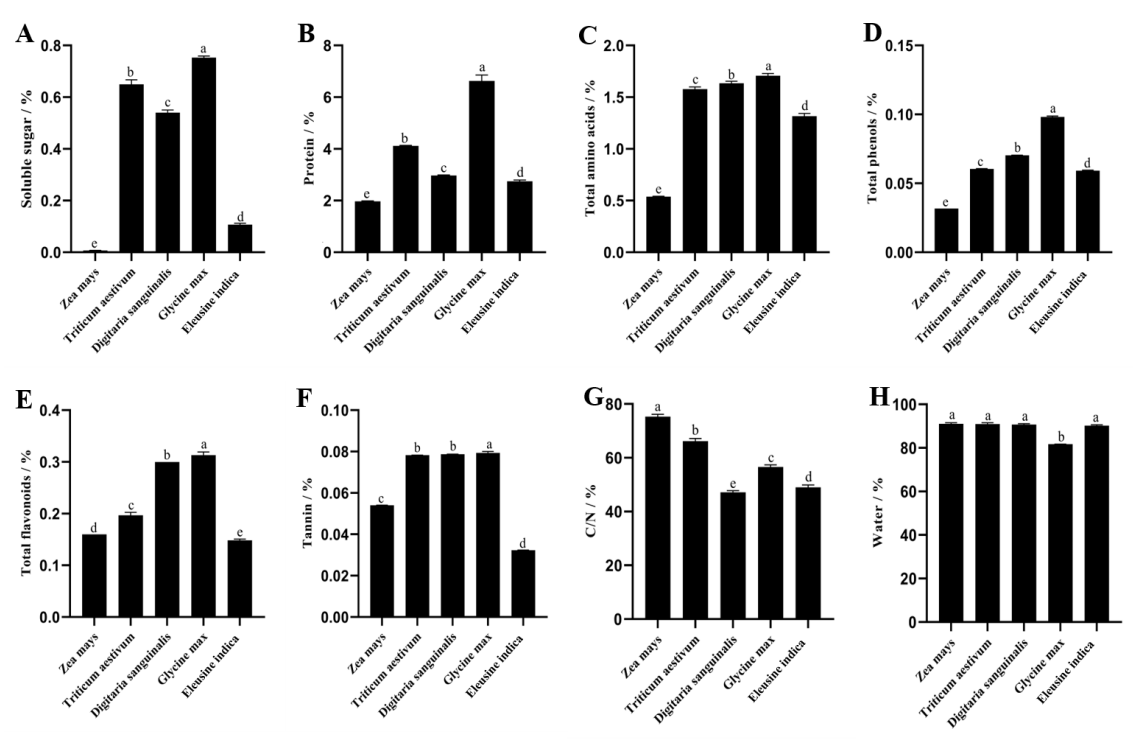